\title{
FROM ACTIVE LURKERS TO COMMUNITY LEADER: WHO THEY ARE AND WHAT THEY DO
}

\author{
Assist. Prof. Dr. Turgay ALAKURT \\ Faculty of Education \\ Dumlupinar University, Turkey
}

\section{ABSTRACT}

In this study, an email-based community supporting a community of practice (CoP) of mathematic teachers was investigated. Public messages members send were examined in order to determine what activities that were conducted by the members and what their level of participation is. Data was gathered via a "Media Records Evaluation Form". A content analysis of these messages revealed that the most frequent activity was views/chat, followed by appreciation and knowledge sharing. Findings also indicate that the least activities were apology, administrative and congratulations. In a CoP, membership is a personal matter and members represent different aspects of participation. In this sense, members' level of participation were determined by using clustering analysis. The results show that there are five different types of participation defined as community leader, core members, active members, peripheral members and active lurkers. However, research findings also point at a sixth group who never participate in knowledge sharing and exchange.

Keywords: knowledge sharing; CoP; community members; level of participation.

\section{INTRODUCTION}

In terms of sharing knowledge, technology, being one of the organizational sources of knowledge management, provides ample opportunities for individuals in producing and distributing knowledge (Yu, Lu, and Liu, 2010). Today, new online communication paradigms which satisfy basic human needs, enable interpersonal communication independent of time and place, and which are based on information and communication technologies, have been developed. Online communities constitute one of these communication paradigms (Stanoevska-Slabeva and Schmid, 2001). Seen as social phenomenon at the beginning of the development of internet technology, these communities have come to the fore as a popular concept with the widespread use of technology. As a result, although many groups have different characteristics, they are called communities. Even among online designers and developers, groups that are in interaction under a heading are called community. Preece (2000) indicates that in order for a group to be considered a community, it should be composed of the following components:

1. People: They interact with each other socially, because they are eager to play such special roles as leadership, chairmanship, pioneering, and they are eager to cater to their own needs.

2. Common Goal: It is an interest, need, information exchange or service that bears a reason for the formation of the community. 
3. Rules: These are the laws, rules, protocols, rituals, assumptions that are not verbally expressed, and they guide the interaction among people.

4. Computer systems: It facilitates and supports social interaction that enhances the sense of solidarity.

\section{COMMUNITIES OF PRACTICE}

First coined by Lave and Wegner (1991), "Communities of practice are groups of people who share a concern, a set of problems, or a passion about a topic, and who deepen their knowledge and expertise in this area by interacting on an ongoing basis" (Wenger, McDermott, and Synder, 2002). Not all communities are communities of practice (Table 1). In order for a community to be considered a community of practice, its members should gather around a common interest (domain), they should be engaged in common activities and discussions that would enhance their ties (community), and they should form a common accumulation of resources (practice).

This does not, however, denote a new idea. According to Wegner (1998), communities of practice are environments where community identity is developed, meaning is constructed, learning is realized, and consensus is reached through mutual interaction. Members interact within a common application. Within application, which constitutes an important part of the community, are three dimensions of the relationship. The first one of these is mutual engagement which denotes the pattern and quantity of the interaction among members. Members form new norms as a result of this interaction by shaping group culture and applications. Being a member of a group does not merely mean being a member. Interaction with other members is also required. Secondly, the common purpose of members that ties them together constructs a joint enterprise that denotes securing consistency in actions and a unifying goal. Lastly, such shared and commonly used repertoire as stories, techniques, tools, forms, symbols, mental categories, concepts, short cuts formed by members in time constitute the thirds dimension of interaction.

As a result of this interaction, in the long and short run, members of the community can find solutions to the problems they face, and can develop new solutions related to the problems through anticipation as well as their knowhow, different perspectives and skills. Moreover, by way of forming a common synergy, calculated risks such as trying new methods can be taken. Members coordinately labour over a problem in order to find a solution to it. Communities of practice are not merely communities that deal with problems. They are also communities in which members create sustainable values that correspond with the community's long-term objectives, real applications within real contexts. In addition, members of the community contribute to their professional growth by means of constructing a database, mutually sharing knowhow, skills, and experience, and following advancements in relation to their fields. In addition to equipping them with short or long term values, communities of practice help their members in providing concrete or abstract gains such as enabling them prepare handbooks, improving skills or accessing information more rapidly. For instance, such less concrete values as improving the sense of trust or increase in the skill of putting forth a new product develop due to the mutual interaction among the community. However, the biggest value that a community of practice provides for its members is composed of abstract outcomes. Friendships 
among members, sense of belonging, professional trust, and increased sense of solidarity can be given as examples (Wenger, McDermott and Synder, 2002).

Table 1

Distinctions between communities of practice and other structures

\begin{tabular}{|c|c|c|c|c|c|}
\hline & $\begin{array}{l}\text { What's the } \\
\text { purpose? }\end{array}$ & Who belongs? & $\begin{array}{l}\text { How clear } \\
\text { are the } \\
\text { boundaries? }\end{array}$ & $\begin{array}{l}\text { What hold } \\
\text { them } \\
\text { together? }\end{array}$ & $\begin{array}{l}\text { How long do } \\
\text { they last? }\end{array}$ \\
\hline $\begin{array}{l}\text { Communities } \\
\text { of Practice }\end{array}$ & $\begin{array}{l}\text { To create, } \\
\text { expand and } \\
\text { exchange } \\
\text { knowledge, } \\
\text { and to } \\
\text { develop } \\
\text { individual } \\
\text { capabilities }\end{array}$ & $\begin{array}{l}\text { Self-selection } \\
\text { based on } \\
\text { expertise or } \\
\text { passion for a } \\
\text { topic }\end{array}$ & Fuzzy & $\begin{array}{l}\text { Passion, } \\
\text { commitment, } \\
\text { and } \\
\text { identification } \\
\text { with the group } \\
\text { and its } \\
\text { expertise }\end{array}$ & $\begin{array}{l}\text { Evolve and end } \\
\text { organically (last } \\
\text { as long as there } \\
\text { is relevance to } \\
\text { the topic and } \\
\text { interest in } \\
\text { learning } \\
\text { together) }\end{array}$ \\
\hline $\begin{array}{l}\text { Formal } \\
\text { Departments }\end{array}$ & $\begin{array}{l}\text { To deliver a } \\
\text { product or } \\
\text { service }\end{array}$ & $\begin{array}{l}\text { Everyone who } \\
\text { reports } \\
\text { to the group's } \\
\text { manager }\end{array}$ & Clear & $\begin{array}{l}\text { Job } \\
\text { requirements } \\
\text { and common } \\
\text { goals }\end{array}$ & $\begin{array}{l}\text { Intended to be } \\
\text { permanent (but } \\
\text { last until the } \\
\text { next } \\
\text { reorganization) }\end{array}$ \\
\hline $\begin{array}{l}\text { Operational } \\
\text { Teams }\end{array}$ & $\begin{array}{l}\text { To take care } \\
\text { of an } \\
\text { ongoing } \\
\text { operation or } \\
\text { process }\end{array}$ & $\begin{array}{l}\text { Membership } \\
\text { assigned by } \\
\text { management }\end{array}$ & Clear & $\begin{array}{l}\text { Shared } \\
\text { responsibility } \\
\text { for the } \\
\text { operation }\end{array}$ & $\begin{array}{l}\text { Intended to be } \\
\text { ongoing (but } \\
\text { last as long as } \\
\text { the operation is } \\
\text { needed) }\end{array}$ \\
\hline $\begin{array}{l}\text { Project } \\
\text { Teams }\end{array}$ & $\begin{array}{l}\text { To } \\
\text { accomplish a } \\
\text { specified } \\
\text { task }\end{array}$ & $\begin{array}{l}\text { People who } \\
\text { have a direct } \\
\text { role in } \\
\text { accomplishing } \\
\text { the task }\end{array}$ & Clear & $\begin{array}{l}\text { The project's } \\
\text { goals and } \\
\text { milestones }\end{array}$ & $\begin{array}{l}\text { Predetermined } \\
\text { ending (when } \\
\text { the project has } \\
\text { been completed) }\end{array}$ \\
\hline $\begin{array}{l}\text { Communities } \\
\text { of Interest }\end{array}$ & $\begin{array}{l}\text { To be } \\
\text { informed }\end{array}$ & $\begin{array}{l}\text { Whoever is } \\
\text { interested }\end{array}$ & Fuzzy & $\begin{array}{l}\text { Access to } \\
\text { information } \\
\text { and sense of } \\
\text { like- } \\
\text { mindedness }\end{array}$ & $\begin{array}{l}\text { Evolve and end } \\
\text { organically }\end{array}$ \\
\hline $\begin{array}{l}\text { Informal } \\
\text { Networks }\end{array}$ & $\begin{array}{l}\text { To receive } \\
\text { and pass on } \\
\text { information, } \\
\text { to know who } \\
\text { is who }\end{array}$ & $\begin{array}{l}\text { Friends and } \\
\text { business } \\
\text { acquaintances, } \\
\text { friends of } \\
\text { friends }\end{array}$ & Undefined & $\begin{array}{l}\text { Mutual need } \\
\text { and } \\
\text { relationships }\end{array}$ & $\begin{array}{l}\text { Never really } \\
\text { start or end } \\
\text { (exist as long as } \\
\text { people keep in } \\
\text { touch } \\
\text { remember each } \\
\text { other) }\end{array}$ \\
\hline
\end{tabular}

Note: Adapted from Cultivating Communities of Practice: A Guide to Managing Knowledge, p. 42, by E. Wenger, R. McDermott, and W. Synder, 2002, Cambridge, MA: Harward Business School Press.

In his study where he focuses on the factors influencing the sharing of knowledge among virtual communities of practice, Alakurt (2013), too, indicates that material reasons for joining a community, which denote the concrete opportunity related to people's professional or private lives (finding solutions to daily problems, benefiting from other members' experience, being informed about professional advancements, course plans, exam questions, official document samples, etc.), are on the fore. Formed in various different fields from health to education, from e-trade to law, communities of practice bring people together, and they are an important tool and site in which people can find solutions to their social and professional problems (Preece, 2000; Timbrell, Lambe and Taule, 2007). However, differences behind the reasons for members' participation to the 
community affect their participation levels to sharing of knowledge processes, and results in their assuming new roles and behaviours. Even when they are communities where large levels of participation to knowledge sharing processes is present, most of this sharing is done by a small number of members. Some members rarely share, and many members merely read the sharing and do not participate (Preece, Nonnecke, and Andrews, 2004; Zhang and Storck, 2001). In this research, knowledge sharing processes in a community of practice and the members' level of participation to this tried to be determined. Thus, the aim is to make sense of the interaction among members through roles and behavior structures. To this end, this research seeks to answer the following questions:

1. What activities do members engage in during knowledge sharing processes?

2. What are the levels of participation of members?

3. Do the activities members realize differ according to their level of participation?

\section{METHODOLOGY}

\section{Study Group}

The study group of this research consists of communities that meet the criteria below:

- They carry the domain, community, and practice characteristics as indicated by Wenger, McDermott, and Snyder (2001).

- They are founded intended for a specific discipline at the national and secondary school level.

- They have more than $\mathbf{1 0 0 0}$ members

- They meet at least twice, in meetings that are held face-to-face.

As a result of the Google search, an email-based community (ILKMATZUM) that meets these criteria consists of the study group. This community was founded in 2006 as a sharing, discussion, chat, and news group for mathematics teachers. Only the members can view the content, and anyone can apply for subscription. Between 2006 and 2013, they held three meetings where members meet. Structural features of the community are given in Table 2.

Table 2

Characteristic of the community

\begin{tabular}{lll}
\hline Categories* & & \\
\hline \multirow{3}{*}{ Demographics } & $\begin{array}{l}\text { Orientation } \\
\text { Life Span } \\
\text { Age }\end{array}$ & $\begin{array}{l}\text { Operational } \\
\text { Permanent } \\
\text { Level of Maturity }\end{array}$ \\
\cline { 2 - 3 } $\begin{array}{l}\text { Organizational } \\
\text { Context }\end{array}$ & $\begin{array}{l}\text { Creation Process } \\
\text { Leadership }\end{array}$ & $\begin{array}{l}\text { Spontaneous } \\
\text { Continuously Negotiated }\end{array}$ \\
\cline { 2 - 3 } & Size & $\begin{array}{l}\text { Large (>2500) } \\
\text { High }\end{array}$ \\
Membership & $\begin{array}{l}\text { Geographic Dispersion } \\
\text { Open }\end{array}$ \\
Characteristics & $\begin{array}{l}\text { Members' Selection Process } \\
\text { Membership Stability }\end{array}$ & $\begin{array}{l}\text { Open } \\
\text { Extensive }\end{array}$ \\
& $\begin{array}{l}\text { Cultural Diversity (same profession, } \\
\text { language, vision) }\end{array}$ & $\begin{array}{l}\text { Fluid } \\
\text { Heterogeneous (Teachers, } \\
\text { parents, students etc.) }\end{array}$ \\
\cline { 2 - 3 } Technological & Degree of Reliance on ICT & High \\
Environment & ICT Availability & High Variety \\
\hline
\end{tabular}

Note: Adapted from Dubé, Bourhis and Jacob, 2006.

The community actively uses social networks (facebook and twitter) and forum fields in their knowledge sharing processes. In today's world where there are approximately 200 
billion emails sent all over the world (http://www.worldometers.info/tr/), such tools have become important parts of knowledge sharing processes because email services are free, because they do not put extra effort on part of the admin, and because one email account is enough to access all group content and other applications.

Public messages members send were examined in order to determine what activities group members are engaged in and what their level of participation is. Data was gathered by using extreme (deviant) case sampling, which is one of the purposive sampling methods within qualitative research tradition. This sampling method that anticipates situations, which are on a singular or limited case but are rich in information, enables one to reach detailed information (Yildirim and Simsek, 2005). One other reason for selecting this sampling method is to prevent misunderstandings and meaning confusions by interpreting the messages sent by members within their own contexts. To this end, a total of 10248 message samples that were sent between 2007 and 2013 were selected, and these samples were selected from the months that have the least and the most message sending frequency (Table 3 ).

Table 3

Sample (The number of messages)

\begin{tabular}{lccccc}
\hline & \multicolumn{2}{c}{ Archived in the listserv } & \multicolumn{2}{c}{ Sample* } & \multirow{2}{*}{ Total } \\
\cline { 2 - 5 } & Max & Min & Max & Min & \\
\hline 2007 & 613 & 49 & 611 & 45 & 656 \\
2008 & 1798 & 33 & 1684 & 24 & 1708 \\
2009 & 1818 & 134 & 1687 & 121 & 1808 \\
2010 & 1131 & 178 & 1093 & 129 & 1222 \\
2011 & 1051 & 133 & 1040 & 106 & 1146 \\
2012 & 1413 & 183 & 1317 & 161 & 1478 \\
2013 & 2245 & 100 & 2137 & 93 & 2230 \\
\hline Total & 10069 & 810 & 9569 & 679 & 10248 \\
\hline
\end{tabular}

*Duplicated and empty messages were omitted.

\section{Data Gathering Tools}

In order to determine which activities members of the community are engaged in, a "Media Records Evaluation Form" was used. A coding key developed by Hew and Hara (2007) was used in preparing the form. During this preparation process, randomly selected 207 analysis units were sent to two coders. Selected coders are faculty members who are experts in the field of educational sciences and qualitative research. Analysis units sent to coders comprise of $2 \%$ of all analysis units. Researcher and the two coders have come together and reached a consensus related to the categories by adding two new categories (View/Chat and Congratulation) to the coding scheme developed by Hew and Hara (2007).

Table 4

Coding scheme

\begin{tabular}{|c|c|c|}
\hline Categories & Definition & Examples \\
\hline View/Chat & $\begin{array}{l}\text { Sharing views on current or social } \\
\text { issues }\end{array}$ & $\begin{array}{l}\text { "...I have searched this seller but it } \\
\text { turns out that he is not really } \\
\text { trustworthy... }\end{array}$ \\
\hline Congratulations & $\begin{array}{l}\text { Congratulating special days or } \\
\text { situations (birth, marriage, etc.) }\end{array}$ & "Happy Teachers' Day" \\
\hline Request & $\begin{array}{l}\text { Requesting an information, an } \\
\text { idea, or participation }\end{array}$ & $\begin{array}{l}\text { "Thank you. God bless you. Do you also } \\
\text { have this for geometry? If you do, that } \\
\text { would be really appreciated. Kind } \\
\text { regards." }\end{array}$ \\
\hline
\end{tabular}




\begin{tabular}{|c|c|c|}
\hline Appreciation & Thanking for an action, & $\begin{array}{l}\text { "Thank you professor, this is a study I } \\
\text { will profusely make use of." }\end{array}$ \\
\hline Administrative & $\begin{array}{l}\text { It includes admin-related } \\
\text { messages as well as messages } \\
\text { related to the use of the } \\
\text { communication tool. }\end{array}$ & $\begin{array}{l}\text { "If there are any topic links missing, } \\
\text { please copy the link of the topic and } \\
\text { answer it with a small note so that all } \\
\text { sources are gathered under one topic } \\
\text { heading..." }\end{array}$ \\
\hline Announcement & $\begin{array}{l}\text { Announcing related news } \\
\text { (activities, information, etc.) } \\
\text { Apologizing for a mistake, error, } \\
\text { or delay }\end{array}$ & $\begin{array}{l}\text { "There is a vacancy for Math and } \\
\text { Science Education Teachers in our } \\
\text { private teaching institution in ...." } \\
\text { "I beg your pardon for the mistake." }\end{array}$ \\
\hline Clarification & $\begin{array}{l}\text { Giving detailed info about a topic } \\
\text { that is not related to the field } \\
\text { (usually in reply to a question) }\end{array}$ & $\begin{array}{l}\text { "...open the lid, put the test in, scan, } \\
\text { and take it back. Then put another one } \\
\text { in ... (it is) a long haul ... prices start } \\
\text { from } 50 \mathrm{TL} \text {. The other is document- } \\
\text { feeding style. That is, all inclusive } \\
\text { (scanner, printer, fax machine) prices } \\
\text { start from } 350 \text { TL... }\end{array}$ \\
\hline $\begin{array}{l}\text { Sharing } \\
\text { Knowledge }\end{array}$ & $\begin{array}{l}\text { Sharing subject matter } \\
\text { knowledge related to the field } \\
\text { (personal view, suggestion, } \\
\text { sources, etc.) }\end{array}$ & $\begin{array}{l}\text { "Here is the original question: there } \\
\text { are } 5 \text { cards in a bag ... When a card is } \\
\text { randomly picked from the bag, what is } \\
\text { the probability of the decrease in } \\
\text { standard deviation for the remaining } \\
\text { numbers? Answer: if numbers } \\
\text { whose...Thus, these numbers are } 1 \text { and } \\
5 \text {. The answer is } 2 / 5 \text {. }\end{array}$ \\
\hline
\end{tabular}

Defined categories were re-coded by two coders who are experts in education and qualitative researches. In determining the reliability between coders, Krippendorff' alpha was calculated as $\mathbf{0 . 6 6 1}$, Cohen's kappa was calculated as 0.659 and Scott-pi was calculated as $\mathbf{0 . 6 5 8}$.

\section{Data Analysis}

Messages composing the sample and the info of members who have sent these messages were recorded by the researcher. In order to determine in which activities members engage, data obtained from the system records of the community were analysed by content analysis. In order to determine the level of community participation in knowledge sharing processes, total number of messages sent between 2007 and 2013 were taken as criterion. In this sense, levels of participation were tried to be determined by grouping members by using clustering analysis, which is a multi-variant statistical technique that helps dividing units, whose groups are not definitely known, into similar sub-clusters. In the clustering analysis, furthest neighbour technique was used; in determining the distance between variants, Euclidian distance was used. Moreover, in order to determine whether activities realized among members differ according to their participation levels, chi-square test was used since related variants are categorical. In the analysis of data, SPSS 17.0 for Windows (Release 17.0.0) software was used.

\section{FINDINGS}

\section{What Activities do Members Engage in During Knowledge Sharing Processes?}

In order to determine which activities community members engage in, 10248 messages were analysed by content analysis. As a result of this analysis, activities were grouped under 9 categories (Table 5). 
Table 5

Types of activities

\begin{tabular}{lrr}
\hline Activity & $\mathbf{n}$ & $\%$ \\
\hline View/Chat & 3589 & 35 \\
Appreciation & 3337 & 32.6 \\
Sharing knowledge & 2115 & 20.6 \\
Request & 631 & 6.2 \\
Clarification & 342 & 3.3 \\
Announcement & 81 & .8 \\
Congratulations & 77 & .8 \\
Administrative & 55 & .5 \\
Apology & 21 & .2 \\
\hline Total & 10248 & 100.0 \\
\hline
\end{tabular}

When Table 5 is examined, it can be seen that views/chat is the most frequent activity among members (35\%). This is followed by appreciation $(32.6 \%)$, knowledge sharing $(20.6 \%)$, and request $(.2 \%)$, respectively. Analysis findings also indicate that the least realized activities are apology $(.2 \%)$ administrative $(.5 \%)$, and congratulations $(.8 \%)$, respectively.

\section{What are the Levels of Participation of Members?}

In order to determine members' level of participation, how many different members the messages in the sample were sent by was investigated. As a result, it was determined that 753 of the messages $(25.2 \%)$ were sent by different members. When the vertical icicle graphic belonging to the clustering analysis of messages of members were examined, it was seen that there are five different participation types. These participation types can be defined as follows:

Community Leader: An email-based community can be created by a single member. Usually, this founding member who is also considered as the community leader is also the owner and admin of the community. By determining the foundation objective of the community, this person constitutes the most important human resource that enables the formation of a common ground and identity among members. Having a 21-messageaverage per month and the most frequent sharing in the group, community leaders are naturally core members at the same time. In time, core members may become community leaders. The community examined within the scope of this study has two community leaders. One of them is the founder, and the other is an ex core member who moves to the next level with his/her sharing and activities.

\section{Core Members}

After the community leader, they are the most active members in sharing knowledge. Core members $(n=7)$ with a 15 -message-per-month average also assume such special roles as leadership or pioneer ship in time. Being key figures for the survival of the community, these members follow the community and participate in sharing on a regular basis. Core members help the community to grow and improve both by their sharings and because of their common passion and expertise, and they also steer discussion within the community. Having the potential to become community leaders in time, these members usually use their real names, and regularly upgrade the info on their profile pages. This helps the growth of a sense of confidence among members.

\section{Active Members}

Members whose contribution to knowledge sharing processes is not as high as core members but who frequently send messages constitute this group $(n=11)$. With a 9 message per month average, active members are self-motivated to improve their 
common fields of interest and their expertise in these, they are highly willing to help other members. Showing great devotion, they work diligently in the activities of the community; moreover, they contribute to the community by providing new points of view, ideas, and suggestions necessary for its growth and improvement.

\section{Peripheral Members}

Those who closely follow knowledge sharing processes in the community and who occasionally send messages comprise this group $(n=30)$. With a less than 4 messages per month average, peripheral members function as a tool for the construction of deep social ties among members of the community.

Active Lurkers: They are the members that constitute the big silent majority in the community $(n=703)$. They do not frequently share in the community, and their group attachment is low; active lurkers are active readers rather than passive members. For them, whatever is shared in the community (class notes, exam samples, presentations, etc.) is more valuable than interacting with other members.

Do the Activities Members Realize Differ according to Their Level of Participation?

Chi-square results showing whether there is a difference in activities according to members' participation levels or whether it is related to their participation levels are given in Table 6.

Table 6

Chi-square test results of activities according to members' participation levels

\begin{tabular}{|c|c|c|c|c|c|c|c|c|c|c|c|c|}
\hline \multirow{3}{*}{ Types of activity } & \multicolumn{10}{|c|}{ Level of Participation } & & \\
\hline & \multicolumn{2}{|c|}{$\begin{array}{l}\text { Community } \\
\text { Leader }\end{array}$} & \multicolumn{2}{|c|}{$\begin{array}{c}\text { Core } \\
\text { Members }\end{array}$} & \multicolumn{2}{|c|}{$\begin{array}{l}\text { Active } \\
\text { Members }\end{array}$} & \multicolumn{2}{|c|}{$\begin{array}{l}\text { Peripheral } \\
\text { Members }\end{array}$} & \multicolumn{2}{|c|}{ Active Lurkers } & \multicolumn{2}{|c|}{ Total } \\
\hline & $\mathbf{n}$ & $\%$ & $\mathbf{n}$ & $\%$ & $\mathbf{n}$ & $\%$ & $\mathbf{n}$ & $\%$ & $\mathbf{n}$ & $\%$ & $\mathbf{N}$ & $\%$ \\
\hline View/Chat & 487 & 13.6 & 420 & 11.7 & 600 & 16.7 & 511 & 14.2 & 1571 & 43.8 & 3589 & 100.0 \\
\hline Appreciation & 55 & 1.6 & 999 & 29.9 & 448 & 13.4 & 735 & 22.0 & 1100 & 33.0 & 3337 & 100.0 \\
\hline $\begin{array}{l}\text { Sharing } \\
\text { knowledge }\end{array}$ & 81 & 3.8 & 206 & 9.7 & 305 & 14.4 & 278 & 13.1 & 1245 & 58.9 & 2115 & 100.0 \\
\hline Request & 21 & 3.3 & 32 & 7.0 & 44 & 7.0 & 79 & 12.5 & 455 & 72.1 & 631 & 100.0 \\
\hline Clarification & 50 & 14.6 & 64 & 18.7 & 43 & 12.6 & 45 & 13.2 & 140 & 40.9 & 342 & 100.0 \\
\hline Announcement & 18 & 22.2 & 5 & 6.2 & 2 & 2.5 & 5 & 6.2 & 51 & 63.0 & 81 & 100.0 \\
\hline Congratulations & 4 & 5.2 & 14 & 18.2 & 10 & 13.0 & 16 & 20.8 & 33 & 42.9 & 77 & 100.0 \\
\hline Administrative & 25 & 45.5 & 2 & 3.6 & 26 & 47.3 & 1 & 1.8 & 1 & 1.8 & 55 & 100.0 \\
\hline Apology & 5 & 23.8 & 2 & 9.5 & $\mathbf{0}$ & 0.0 & $\mathbf{0}$ & 0.0 & 14 & 66.7 & 21 & 100.0 \\
\hline Total & 746 & 7.3 & 1744 & 17.0 & 1478 & 14.4 & 1670 & 16.3 & 4610 & 45.0 & 10248 & 100.0 \\
\hline
\end{tabular}

When Table 6 is examined, it can be seen that messages sent by community leaders who constitute the cluster with the least number of members $(n=2)$ constitute $7.3 \%$ of the messages forming the sampling, core members' $(n=7)$ messages constitute $17.0 \%$, active members' $(n=11)$ messages constitute $14.4 \%$, peripheral members' $(n=30)$ messages constitute $16.3 \%$, and messages of active lurkers' $(n=703)$ who make of the largest cluster constitute $45.0 \%$ of the sample messages. This difference observed between the members' participation levels and the activities was found statistically significant $\left[\chi_{(32)}^{2}=\right.$ $1616.132, p<.05]$. In other words, there is a meaningful relationship between members' level of participation and the activities they engage in.

\section{DISCUSSION AND CONCLUSION}

In this study, I tried to determine in which activities members of a community of practice engage in their knowledge sharing processes and what behavior and roles they exhibit by examining their levels of participation. Research findings indicate that members engage, in order of frequency, in view/chat $(35.0 \%)$, appreciation $(32.6 \%)$, and knowledge 
sharing (20.6\%). Activities members engage in the least are apology $(.2 \%)$, administrative $(.5 \%)$, and congratulation $(.8 \%)$. These findings are partially similar to the findings of Hew and Hara's (2007) study. Examining knowledge sharing behavior of literacy teachers who are subscribers to an email list, researchers indicate that members engage mostly in knowledge sharing $(60.8 \%)$ and request $(25.7 \%)$ activities. In his study where he examined the knowledge sharing behavior of the members of 6 communities of practice, Alakurt (2013) also states that the most frequent activity is knowledge sharing $(30.8 \%)$ among members. This activity is followed by view/chat $(22.7 \%)$, request $(15.8 \%)$, and appreciation $(13.4 \%)$, respectively.

Research findings also indicate that there are five different participation levels in the community of practice, and these members assume different roles and behaviors' in these levels of participation. However, research findings also point at a sixth group who never send messages. Some studies state that the ratio of members who never send messages is 90\% (Katz, 1998; Mason, 1999). Preece, Nonnecke, and Andrews (2004), on the other hand, argue that the number of members who never send messages differ across communities. For instance, in communities about health this ratio is $45.5 \%$ (Nonnecke 2000), and in communities about software, it is $82 \%$ (Nonnecke and Preece, 2000). Moreover in communities established within a company that produces office suppliers this ratio is between \%83.8 and \%51.6 (Takahashi, Fujimoto and Yamasaki , 2003). In this study that examines a community of practice about education, the ratio is around $75 \%$. The development of the "Community" structure of a community of practice is not only mental but also related to the social ties among people. Sharing knowledge requires forming social ties among members (Chen, Chen and Kinshuk, 2009; Suh and Shin, 2010; Gross and Kluge, 2012). In this respect, relations that are based on trust enhance ties among members thereby improving and promoting knowledge sharing processes of communities (Hsu, Ju, Yen and Chang, 2007; Alam, Abdullah, Ishak and Zain, 2009; Lin, Hung and Chen, 2009; Chang and Chuang, 2011). Members who have mutual acquaintances in the community trust each other more (Yuki et al, 2005). In their study in which they examine the behavior of members who send no messages, 3 or less messages in a month, and members who frequently send messages, Ridings, Gefen, and Arinze (2006), too, state that trust levels of those members who send no messages are lower compared to that of other members. In their study where they define those who either send no messages or very rarely as "lurkers," Nonnecke and Preece (2001) examine why these members do not participate in sharing processes. As a result of their study, they have found out that the most important reasons for lurkers' not sending any messages were listed as "wanted to be anonymous", "work related constraints, e.g., employer did want work email address to be used", "had too many or too few messages to deal with", "received poor quality messages", "were shy about public posting" and "had limited time". In a similar study, it was determined that the following reasons came to the fore: "just reading/surfing is enough", "Still learning about the group", "Shy about posting" and "Nothing to offer" (Nonnecke, Preece, Andrews, and Voutor, 2004).

Communities of practice play a significant role in providing a flow of information. They can be seen as alternative or new ways especially in the realization of new learning, and transferring knowledge to less experienced and less-expert members by experienced and expert members. Active members, core members, and community leader, who comprise of a small group in the community, contribute greatly to the knowledge sharing processes for the survival of the community. Nevertheless, it cannot be claimed that active lurkers, who make up of the group with the most number of members, contribute much to knowledge sharing processes individually. Preece, Nonnecke, and Andrews (2004) suggest several strategies to increase their participation and integration to the community.

- Encouragement of the admins (sending PMs, introducing the new members to the group, or having them to introduce themselves to the community) 
- Ensuring new members get acquainted with the community by providing guidance and counselling.

- Rewarding members who contribute to the community.

- Certain members (preferably from core or active members) becoming role models. This also helps increase content-wise quality messages.

- Making the site more user-friendly by dealing with the confusion and disorganization in the interface design (Forming clear directions about access to the interface, reading messages, sending new messages, and starting discussions, etc.)

- Surfing without getting lost among the many messages sent to the community. To this end, content maps can be prepared or the community can be divided into small units (e.g., members who know each other better can form a subgroup)

- Admins never leaving any message (especially those sent by active lurkers) unanswered in order to remedy the weak interaction among members, or admins delegating this job to other members (core, active, or peripheral members).

Some of the above-mentioned strategies were observed to be applied in the examined community of practice. For instance, most of the community leaders, core members, and active members share their personal info (real name, school they work at, business or personal telephone numbers) on their profile pages or messages. In addition to strengthening ties or trust and enabling members to get to know each other better, this proves to be setting good role models for new members and members who send very little messages. Moreover, it can be seen that there is a high level of appreciation activity (32.6\%) among members. It's been thought that thanking other members for sharing, expressing praise and gratitude has an influence for the strengthening of this tie. In the selection of the community that constitutes the study group; face-to-face interaction among members was a criterion. In this respect, it can be claimed that meeting face to face enhances the sense of trust and results in members getting better acquainted with each other. Lastly, as Preece, Nonnecke, and Andrews (2004) point out, it was observed that the community is divided into a small sub-group called "special group" which is composed mostly of core and active members. Self-motivated members (especially peripheral members) participate more in sharing processes in order to receive an invitation to this "special group."

Although individually active lurkers participate minimally to the community, when considered as a whole, they provide more to the knowledge sharing processes of the community compared to other groups. This finding is similar to the findings of Zhang ad Storck's study (2001) in which they examine the members' behaviors of a travel forum site. This draws attention to the potential contribution active lurkers who tend to leave the community earlier. Maybe, a community's transition to an upper level depends on what roles its members play in the community. Active lurkers and those who never send messages share either too little or no information about themselves. Qualitative and quantitative research that seeks answers to such questions as how can these members assume more participatory roles, what motivates them, and how can their sense of trust to other members be improved can help improving knowledge sharing processes.

\section{BIODATA and CONTACT ADDRESSES of the AUTHOR}

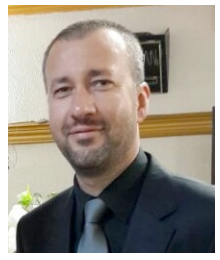

Dr. Turgay ALAKURT is currently the vice-chairman of Turkish Association of Information and Communication Technologies Educators (BTE). He participates in a variety of academic forums, authoring articles and presentations in the area of instructional technology. His research interests include computer ethics, knowledge management, knowledge sharing and communities of practice. 
Assist. Prof. Dr. Turgay ALAKURT,

Faculty of Education, Department of Computer Education and Instructional Technology,

Dumlupinar University, Kütahya, Turkey.

Phone: +902742652031 - 4611,

E-mail: turgay.alakurt@dpu.edu.tr

\section{REFERENCES}

Alakurt, T. (2013). An analysis of the factors influencing knowledge sharing behaviours between members of virtual communities of practice (Doctoral dissertation). Ankara University Institute of Educational Sciences. Ankara.

Alam, S. S., Abdullah, Z., Ishak, N. A. \& Zain, Z. M. (2009). Assessing knowledge sharing behaviour among employees in SMEs: An empirical study. International Business Research, 2(2), 115-22.

Chang, H. H. ve Chuang, S.-S. (2011). Social capital and individual motivations on knowledge sharing: Participant involvement as a moderator. Information \& Management, 48(1), 9-18.

Chen, I. Y. L., Chen, N.-S. \& Kinshuk. (2009). Examining the Factors Influencing Participants' Knowledge Sharing Behavior in Virtual Learning Communities. Educational Technology \& Society, 12(1), 134-148.

Dubé, L., Bourhis, A. \& Jacob, R. (2006). Towards a Typology of Virtual Communities of Practice. Interdisciplinary Journal of Information, Knowledge, and Management, 1, 69-93.

Gross, N. \& Kluge, A. (2012). "Why should I share what I know?" -Antecedents for enhancing knowledge-sharing behavior and its impact on shared mental models in steel production. Proceedings of the Human Factors and Ergonomics Society Annual Meeting, 56(1), 403-407.

Hew, K. F. \& Hara, N. (2007). Empirical Study of Motivators and Barriers of Teacher Online Knowledge Sharing. Educational Technology Research and Development, 55(6), 573-595.

Hsu, M.-H., Ju, T. L., Yen, C.-H. \& Chang, C.-M. (2007). Knowledge sharing behavior in virtual communities: The relationship between trust, self-efficacy, and outcome expectations. International Journal of Human-Computer Studies, 65(2), 153-169.

Katz, J. (1998). Luring the lurkers. Retrieved from http://beta.slashdot.org/story/3892

Lin, M.-J. J., Hung, S.-W. \& Chen, C.-J. (2009). Fostering the determinants of knowledge sharing in professional virtual communities. Computers in Human Behavior, 25(4), 929939.

Mason, B. (1999). Issues in virtual ethnography. Proceeding of Ethnographic Studies in Real and Virtual Environments: Inhabited Information Spaces and Connected Communities, Edinburgh.

Nonnecke, B. (2000). Lurking in email-based discussion lists (Doctoral dissertation). South Bank University, London.

Nonnecke, B., \& Preece, J. (2000). Lurker demographics: counting the silent. Paper presented at the ACM CHI 2000 conference on human factors in computing systems, The Hague. 
Nonnecke, B., \& Preece, J. (2001). Why lurkers lurk. Paper presented at the Americas Conference on Information Systems, Boston.

Nonnecke, B., Preece, J., Andrews, D., \& Voutour, R. (2004). Online lurkers tell why. Paper presented at the Tenth Americas Conference on Information Systems, New York.

Preece, J., Nonnecke, B., \& Andrews, D. (2004). The Top Five Reasons for Lurking: Improving Community Experiences for Everyone. Computers in Human Behavior. 20, 201223.

Preece, J. (2000). Online communities: designing usability, supporting sociability. Chichester, UK: John Wiley \& Sons.

Ridings. C., Gefen, David., \& Arinze, B. (2006). Psychological Barriers: Lurker and Poster Motivation and Behavior in Online Communities. Communications of the Association for Information Systems. 18, 329-354.

Stanoevska-Slabeva, K. \& Schmid, B. F. (2001). A typology of online communities and community supporting platforms. Proceedings of the 34th Hawaii International Conference on System Sciences.

Suh, A. \& Shin, K.-S. (2010). Exploring the effects of online social ties on knowledge sharing: A comparative analysis of collocated vs dispersed teams. J. Inf. Sci., 36(4), 443463.

McLure Wasko, M. \& Faraj, S. (2000). "It is what one does": Why People Participate and Help Others in Electronic Communities of Practice. The Journal of Strategic Information Systems, 9(2-3), 155-173.

Takahashi, M., Fujimoto, M., \& Yamasaki, N. (2003). The active lurker: influence of an inhouse online community on its outside environment. Paper presented at the Group 2003 International ACM SIGGROUP Conference on Supporting Group Work, Sanibel Island, Florida.

Timbrell, G., Lambe, P. \& Taule, Q. (2007). Throwing Pebbles into a Dark Cave: A Study of Participation and Behaviour in the \{act-km\} Online Community. Journal of Information \& Knowledge Management (JIKM), 6(2), 139-152.

Wenger, E. (1998). Communities of Practice: Learning, Meaning, and Identity. Cambridge: Cambridge University Press.

Wenger, E. (2000). Communities of Practice and Social Learning Systems. Organization, 7(2), 225-246.

Wenger, E., McDermott, R. \& Snyder, W. (2002). Cultivating communities of practice: A guide to managing knowledge, Boston, MA: Harvard Business School Press.

Yıldırım, A. \& Şimşek, H. (2005). Sosyal bilimlerde nitel araştirma yöntemleri. (4. Basım). Ankara: Seçkin Yayınları.

Yu, T.-K., Lu, L.-C. \& Liu, T.-F. (2010). Exploring Factors That Influence Knowledge Sharing Behavior via Weblogs. Computers in Human Behavior, 26(1), 32-41.

Yuki, M., Maddux, W., Brewer, M., \& Takemura, K. (2005). Cross-cultural differences in relationship-and group-based trust. Personality and Social Psychology Bulletin, 31(1), 48. 
Zhang, W. \& Storck, J. (2001). Peripheral members in online communities, Paper presented at the AMCIS 2001 conference on human factors in computing systems, Boston. Retrieved from http://ifipwg213.org/system/files/zhang.pdf 